\title{
Quiasmo e imaginación en el "último" Merleau-Ponty
}

\author{
[Chiasm and Imagination in the "Late" Merleau-Ponty]
}

\author{
GERMÁn OSVALDo PRÓSPERI \\ Universidad Nacional de La Plata \\ gerprosperi@hotmail.com
}

\begin{abstract}
Resumen: El concepto de "quiasmo" es fundamental en la filosofía del "último" Merleau-Ponty. Me interesa retomar este concepto para mostrar que, en la nueva ontología esbozada en Le visible et l'invisible y en las notas de la misma época, su función guarda correspondencia con la tarea que, a lo largo de la historia de la filosofía, ha desempeñado la imaginación. En este sentido, una ontología del quiasmo supone por necesidad pensar una ontología de la imaginación. Además, este concepto permite arrojar una luz nueva sobre el problema de la subjetividad.
\end{abstract}

Palabras clave: ontología, pliegue, carne, subjetividad, percepción

\begin{abstract}
The concept of "chiasm" is central to the philosophy of the "late" Merleau-Ponty. My aim is to retrieve this concept in order to show that, within the framework of the new ontology outlined in Le visible et l'invisible and the notes written during the same period, its function corresponds to the function that imagination has performed throughout the history of philosophy. Thus, an ontology of chiasm necessarily involves reflecting upon an ontology of imagination. Furthermore, the concept of chiasm enables us to shed new light on the problem of subjectivity.
\end{abstract}

Key words: ontology, fold, flesh, subjectivity, perception

\section{Introducción}

Como bien han mostrado varios especialistas (entre otros, Toadvine 2012, pp. 336-347; Barbaras 2004, pp. 153-161; Dupond 2001, pp. 68; Hamrick y Van der Veken 2011, pp. 86-94), el concepto de "quiasmo" (chiasme) es fundamental en la filosofía del "último" Merleau-Ponty. En efecto, el capítulo final de Le visible et l'invisible (1964a), texto póstumo que publicó Gallimard bajo el cuidado de Claude Lefort, se titula justamente "El entrelazo - El quiasmo". Según Ted Toadvine, la noción de quiasmo "es la clave para la ontología tardía de Merleau-Ponty, y en particular para su comprensión de la relación entre los humanos y la naturaleza" (Toadvine 2009, p. 107).

Como se sabe, el término "quiasmo" posee dos sentidos fundamentales: uno fisiológico y otro retórico (véanse Toadvine 2012, pp. 336-338; Hamrick y Van der Veken 2011, pp. 86-89). Según el primer sentido, 
designa el punto en el que se cruzan dos estructuras anatómicas tales como fibras, nervios o ligamentos. Por supuesto, el ejemplo paradigmático es el quiasmo óptico. ${ }^{1}$ Según el segundo sentido, designa una

${ }^{1} \mathrm{Al}$ parecer le corresponde a Rufo de Éfeso, famoso médico griego que vivió, según la Suda, en tiempos de Trajano (cfr. Suidas lexicon, s.v. Rouphos), la gloria de haber sido el primero en describir el quiasmo óptico. Como se sabe, los nervios ópticos conectan los ojos con el cerebro. Cada nervio mide unos 3 o $4 \mathrm{~mm}$ y contiene alrededor de 250 mil axones. Luego de pasar por la retina en el disco óptico, el nervio óptico se extiende unos $5 \mathrm{~cm}$ hasta el quiasmo. En los primates y otros mamíferos, los axones que provienen de las retinas se cruzan en el quiasmo y prosiguen hacia el otro lado del cerebro. Este cruzamiento de los axones se denomina "decusación", palabra que proviene del latín decussatio y significa "intersección de dos líneas en forma de cruz". Por su parte, el término "quiasmo" proviene del griego $\chi i ́ \alpha \sigma \mu \alpha$ y posee el mismo significado que la decussatio latina. Claudio Galeno, quien en De usu partium corporis humani utiliza el término griego, reflexiona sobre su sentido y ofrece una explicación del quiasmo óptico: "es extraordinario que [los nervios sensores que descienden del cerebro a los ojos] se originen en lugares diversos y procediendo se unan para luego alejarse y divergir nuevamente. ¿Con qué fin la naturaleza no ha hecho comenzar su crecimiento desde lo alto en el mismo lugar y, después de haber hecho nacer uno de la derecha, el otro de la izquierda, no los ha hecho ir directamente a las regiones (órbitas) de los ojos, sino que los ha plegado antes hacia el interior, los ha ligado y ha unificado sus canales, y después los ha hecho ir cada uno hacia el ojo que se encuentra en línea recta con su surgimiento desde lo alto? La naturaleza no los ha ciertamente intercambiado, haciendo ir el nervio de la parte derecha al ojo izquierdo y el de la parte izquierda al ojo derecho, pero el esquema de estos nervios es muy similar al de la letra X. Quien no haya realizado una disección cuidadosa puede llegar a creer que se cruzan, es decir que se superponen uno al otro. Sin embargo, las cosas no son así; en efecto, se encuentran en el interior del cráneo y unifican sus canales para luego separarse de nuevo" (Galeno 1978, p. 820; a menos que se indique lo contrario, las traducciones son mías). Galeno sostiene que el nombre del quiasmo óptico se deriva de la letra X (chi). Sin embargo, no considera que los canales ópticos (por los que, según su teoría, circula el pneuma [ $\pi \nu \varepsilon \tilde{-}$ $\mu \alpha]$ ) se crucen y se superpongan, sino que meramente se tocan, se encuentran para volver a separarse. Es probable que haya deducido esto al observar que una parte de los nervios ópticos no se cruzan en el quiasmo (sólo se cruzan la mitad de las fibras axónicas, las cuales pasan del nervio óptico a la cinta óptica opuesta), de tal manera que parte del tracto que se origina en el flanco derecho del cerebro desemboca en el ojo derecho, mientras que el tracto izquierdo lo hace en el ojo izquierdo. Más allá de este aspecto, para nada menor, Galeno creía, como se creerá hasta bien entrado el siglo XVII, que las imágenes que provienen de los dos ojos se fusionaban, al ser transportadas por el pneuma que circulaba por el interior de los nervios ópticos, en el quiasmo. En el centro de la X, aunque sin cruzarse ni superponerse, el pneuma visible proveniente de ambos ojos se unificaba en una única imagen y una única experiencia que le llegaba entonces al cerebro. Por ello, la finalidad del quiasmo consiste en la resolución de la diplopía. Gracias a que las dos imágenes, que evidentemente son dispares, se tocan en el quiasmo, vemos objetos singulares y no objetos dobles.

Diánoia, vol. LXIII, no. 80 (mayo de 2018). 
figura discursiva que se forma por la repetición de una estructura en orden inverso. Toadvine cita como ejemplo el siguiente verso de Keats: "La belleza es verdad, la verdad belleza" (Toadvine 2012, p. 336). Si bien ambos sentidos están presentes en Merleau-Ponty, sin duda el primero es el que parece imponerse por su filiación con el asunto de la visión.

Ahora bien, me interesa retomar aquí este concepto de MerleauPonty para mostrar, en el marco de la nueva ontología esbozada en Le visible et l'invisible y en las notas de la misma época, que su función guarda correspondencia con la tarea que, a lo largo de la historia de la filosofía (en términos de Heidegger y Derrida: de la metafísica), ha desempeñado la imaginación. ${ }^{2}$ En este sentido, pensar una ontología del quiasmo (o, como veremos, de la carne $)^{3}$ supone por necesidad pensar una ontología de la imaginación. Además, esta ontología de la imaginación u ontología quiasmática, necesariamente indirecta, permite arrojar una luz nueva sobre el problema — también central en el autor francés- de la subjetividad. Como se verá, el concepto de quiasmo no sólo se aplica a la distinción ontológica entre lo "visible" y lo "invisible" o entre lo "sensible" y lo "inteligible", sino también, y de manera explícita, a la distinción entre la "pasividad" y la "actividad".

Mi exposición se divide en dos secciones. En la primera explicaré en forma rápida el concepto de quiasmo y la razón por la cual propongo identificarlo con la imaginación. En la segunda abordaré -también de manera rápida - el problema de la subjetividad y mostraré que la imaginación es justamente la instancia que articula el aspecto pasivo con el aspecto activo del sujeto.

\section{Imaginación y ontología}

En una nota de trabajo de junio de 1960, Merleau-Ponty precisa cuáles son los dos términos que se articulan en el quiasmo: "Hay un cuerpo del espíritu, y un espíritu del cuerpo y un quiasmo entre ellos" (MerleauPonty 1964a, p. 307). Cuerpo y espíritu, entonces. Sin embargo, la relación entre ambos términos no es de oposición (como en el caso de la

${ }^{2}$ En un texto sugerente, Annabelle Dufourcq, quien casualmente transcribió algunas clases de Gilles Deleuze sobre la imagen en Bergson, se dedica a analizar la relación entre la ontología merleau-pontiana y lo imaginario (véase Dufourcq 2012, en particular pp. 343-402).

${ }^{3}$ El sentido que encierra el concepto de "quiasmo" sólo se vuelve inteligible si se relaciona con otros términos clave de Merleau-Ponty como carne, solapamiento, reversibilidad, profundidad y dehiscencia. 
res cogitans y la res extensa en Descartes o del ser en sí y el ser para sí en Sartre) ni de contradicción o de síntesis (Hegel), sino de solapamiento o encabalgamiento. Hay una pregnancia de lo invisible en lo visible y de lo visible en lo invisible. Lo invisible, el espíritu, no es lo otro de lo visible, sino su otro lado. De la misma manera, lo visible no es lo otro de lo invisible, sino también su otro lado. Son como el derecho y el reverso del ser. Por eso Merleau-Ponty, retomando un motivo cristiano, habla de un cuerpo del espíritu y de un espíritu del cuerpo. ${ }^{4}$ De hecho, en la misma nota aclara:

El "otro lado" quiere decir que el cuerpo, en cuanto que tiene este otro lado, no es descriptible en términos objetivos, en términos de sí -que este otro lado es verdaderamente el otro lado del cuerpo, desborda en él (Überschreiten), se solapa sobre él, está oculto en él一, y al mismo tiempo tiene necesidad de él, se termina en él, se ancla en él. (Merleau-Ponty 1964a, p. 307; las cursivas son del autor)

Por supuesto, el cuerpo no es un objeto, una cosa, pero tampoco es un sujeto, una conciencia o mera negatividad. Hay una suerte de exceso

${ }^{4}$ Por cierto, en 1 Corintios 15:44, Pablo dice: "Se siembra un cuerpo natural

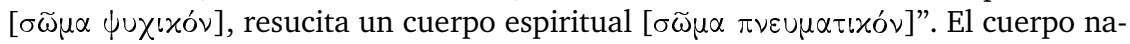
tural y el cuerpo espiritual, la naturaleza (physis) y el espíritu (pneuma, pero también logos), son, por cierto, temas centrales en las cartas paulinas, en particular, y en la teología cristiana, en general. De algún modo, Cristo, es decir, el verbo hecho carne, se sitúa en el pliegue exacto de lo visible y lo invisible, del arquetipo y la copia, del espíritu y la materia. Como dice Pablo en Colosenses 1:15-16: "Él [Cristo] es la imagen del Dios invisible, el Primogénito de toda la creación. Porque por Él fueron creadas todas las cosas, las que hay en el cielo y las que hay en la tierra, visibles e

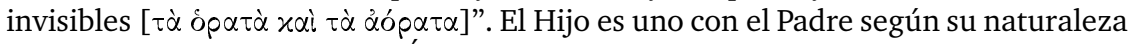
o su esencia, pero diverso de Él según su persona, su hipóstasis. Este doble aspecto de Cristo hace posible la conexión entre Dios y los hombres, entre lo invisible [ $\tau \grave{\alpha}$

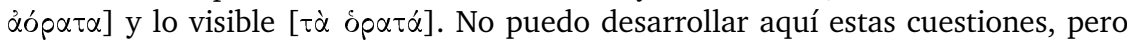
baste decir que en la teología cristiana Jesús es precisamente el quiasmo entre lo visible y lo invisible, entre el verbo y la carne. No resulta desatinado suponer que Merleau-Ponty tuvo presente el concepto cristiano de carne porque, en Le visible et l'invisible, habla de una carne sutil o de un cuerpo glorioso, expresiones que remiten sin duda a la teología cristiana: "Mi carne y la del mundo abarcan entonces zonas claras, días alrededor de los cuales orbitan sus zonas opacas, y la visibilidad primera, la de los quale y de las cosas, no deja de remitir a una visibilidad segunda, la de las líneas de fuerza y las dimensiones, la carne maciza a una carne sutil, el cuerpo momentáneo a un cuerpo glorioso" (Merleau-Ponty 1964a, p. 192). En el siglo $\mathrm{xx}$, el autor que más ha profundizado en una fenomenología de la carne y de la encarnación desde una perspectiva cristiana es, sin duda, Michel Henry (véase, en particular, Henry 2000).

Diánoia, vol. LXIII, no. 80 (mayo de 2018). 
del cuerpo, de misterio o lado oculto que no puede explicarse en términos rigurosamente corporales. Este otro lado, esta especie de sombra solapada, encabalgada al cuerpo, es el espíritu. Y a la inversa: el espíritu no es una conciencia, no es el sentido inaugurado o fundado en un para sí; el espíritu es el pliegue del propio cuerpo, su repulgo, el secreto que lo desborda y al mismo tiempo lo requiere. ${ }^{5} \mathrm{El}$ término que permite pensar esta ontología del solapamiento o de la reversibilidad y, en consecuencia, evitar los dualismos propios del pensamiento moderno, es el de carne (chair). 6 "La noción esencial para tal filosofía es la de la carne, que no es el cuerpo objetivo, que no es tampoco el cuerpo pensado por el alma (Descartes) como suyo, que es lo sensible en el doble sentido de lo que se siente y lo que siente" (Merleau-Ponty 1964a, p. 307). Entonces, no se trata de considerar el cuerpo como objeto y el espíritu como sujeto; no se trata, por lo mismo, de pensar la carne como sustancia:

${ }^{5}$ En su texto sobre Foucault, Gilles Deleuze critica la noción de "pliegue" en Merleau-Ponty (y, más allá, en Heidegger): "Para Merleau-Ponty, el entrelazo, el entre-dos se confunde con el pliegue. Pero no para Foucault. Hay un entrelazamiento, un entrecruzamiento de lo visible y de lo enunciable: es el modelo platónico del tejido que reemplaza a la intencionalidad. Pero este entrelazamiento es un abrazo, una batalla entre dos adversarios irreductibles, las dos formas del ser-saber: si se quiere, es una intencionalidad, pero reversible, y multiplicada en los dos sentidos, devenida infinitesimal o microscópica. No es entonces el pliegue del ser, es el entrelazamiento de sus dos formas" (Deleuze 2004, p. 119).

${ }^{6}$ Sobre el concepto de carne en Merleau-Ponty, véanse Evans y Lawlor 2000; Esposito 2006, pp. 252-271; Carbone 2015, pp. 7-20; Dupond 2001, pp. 5-6; Hamrick y Van der Veken 2011, pp. 73-102, 205-233. En su estudio sobre la pintura de Francis Bacon, Gilles Deleuze concibe la carne como la zona de indistinción entre lo humano y lo animal, es decir, como devenir-animal del hombre: "Esta zona objetiva de indiscernibilidad era ya todo el cuerpo, pero el cuerpo en cuanto que carne o comida" (Deleuze 2002, p. 28). Y, en la medida en que, según Bacon, la carne supone una desarticulación de la identidad humana, se opone al rostro y a los huesos: "Los huesos pertenecen al rostro, no a la cabeza. No hay cabeza de muerte según Bacon. La cabeza es deshuesada más que ósea. Sin embargo, no es del todo blanda, sino firme. La cabeza pertenece a la carne y la máscara misma no es mortuoria, es un bloque de carne firme que se separa de los huesos" (Deleuze 2002, p. 31). Deleuze vuelve a la noción de carne en Qu'est-ce que la philosophie?, donde desarrolla una sutil crítica a Merleau-Ponty y la fenomenología de la carne: "Un extraño Carnismo propicia esta última peripecia de la fenomenología y la sume en el misterio de la encarnación: es una noción pía y sensual a la vez, una mezcla de sensualidad y de religión, sin la que, tal vez, la carne no se sostendría por sí misma" (Deleuze y Guattari 2005, p. 169). Un poco más adelante añade: "La carne no es más que el termómetro de un devenir. La carne es demasiado tierna" (Deleuze y Guattari 2005, p. 169). Sobre la concepción de la carne en la pintura de Bacon según Deleuze, véase Deleuze 2002, pp. 27-38.

Diánoia, vol. LXIII, no. 80 (mayo de 2018). 
la carne es quiasmo, es decir, relación. El filósofo francés sugiere el término "elemento", es decir, "una cosa general, a medio camino del individuo espacio-temporal y de la idea, una suerte de principio encarnado que conlleva un estilo de ser" (Merleau-Ponty 1964a, p. 182). ${ }^{7}$ Curiosamente, esta definición recuerda el concepto de "imagen" propuesto por Henri Bergson en Matière et mémoire, un texto en el que se aborda justo la relación problemática entre el cuerpo y el espíritu (véase Deleuze 1966, p. 6). Cito un pasaje del prefacio a la séptima edición de Matière et mémoire: "Por 'imagen' entendemos cierta existencia que es más que lo que el idealista llama una representación, pero menos que lo que el realista llama una cosa: una existencia situada a medio camino entre la 'cosa' y la 'representación'” (Bergson 1939, pp. 5-6). ${ }^{8}$ Una imagen no es una cosa, pero tampoco es una representación. Este universo de imágenes es independiente de la conciencia. Las imágenes no requieren de ninguna conciencia ni de ningún sujeto para existir. ${ }^{9}$ De algún modo, la imagen se ubica a medio camino entre la cosa y la representación. Se trata de una ontología del "a medio camino", es decir, del quiasmo. De acuerdo con Merleau-Ponty, la carne se ubica a medio camino del individuo espacio-temporal y de la idea; ${ }^{10}$ la imagen, en Bergson, $a$

${ }^{7}$ El término "elemento" que Merleau-Ponty elige para referirse a la carne posee un antecedente ilustre en relación con la imaginación en la persona de Gaston Bachelard. Explica María Noel Lapoujade en un interesante ensayo sobre Bachelard: "Los cuatro elementos son a la vez sustancias y fuerzas del universo y elementos de la imaginación poética" (Lapoujade 2009, p. 41). Según Lapoujade, la imaginación poética de Bachelard implica, a decir verdad, una estética que tiene los alcances de una teoría de la poiesis. Sobre la dimensión estética de la imaginación, véase Lapoujade 2009. Sobre la imaginación y la teoría de las imágenes en Bachelard, véanse Solares 2009 y Bachelard 2005. Sobre la relación entre Merleau-Ponty y Bachelard en lo concerniente a la imaginación y lo imaginario, véanse Dufourcq 2016, pp. 43-58 y Mazis 2016, pp. 255-269. En un capítulo titulado "Bachelard's Material Imagination and the Flesh of the World", Mazis explica la importancia de Bachelard en el pensamiento del último Merleau-Ponty: "La última articulación de lo imaginal en Merleau-Ponty entendido como delineación de lo sensible cuya participación en el ser del mundo es esencial comparte muchas ideas y su perspectiva ontológica general con Gaston Bachelard" (Mazis 2016, p. 255). Además, "Para Bachelard, como para Merleau-Ponty, el giro hacia otra clase de ontología, de latencias, de matices, de un sentido más profundo, asistida por el poder de cierto modo de imaginar, era un asunto vital para la cultura contemporánea occidental" (Mazis 2016, p. 269).

${ }^{8}$ Sobre la relación entre la memoria y la imaginación en Bergson, véase Lapoujade 2002a.

${ }^{9} \mathrm{Al}$ discutir el concepto de imagen en Bergson, Merleau-Ponty habla de "un universo de imágenes sin espectador" (Merleau-Ponty 1995, p. 83).

${ }^{10}$ Con el objetivo de expresar este lugar intermedio de la carne, Merleau-Ponty

Diánoia, vol. LXIII, no. 80 (mayo de 2018). 
medio camino de la cosa y la representación. El estatus ontológico de ambos conceptos, carne e imagen, más allá de sus evidentes (o no tan evidentes) diferencias, es el mismo. ${ }^{11}$ Este "a medio camino", pliegue o quiasmo, es acaso lo más difícil de pensar. Merleau-Ponty indica que se trata de un borde o una juntura, una membrana ontológica. ${ }^{12}$ Por

utiliza muchas veces la expresión, que remite en forma explícita a Marcel Proust, "ideas sensibles". La idealidad en la que piensa el fenomenólogo francés no es, por supuesto, el mundo trascendente de las formas platónicas, sino el aspecto ideal de lo sensible. Si puede hablarse de un plano invisible es siempre considerándolo en relación con lo visible: la idealidad es lo invisible de lo visible. Esto significa que las ideas son inmanentes a lo sensible. No es casual que Deleuze encuentre también en Proust esta suerte de idealidad inmanente: "El sentido mismo se confunde con esta desenvoltura del signo, así como el signo se confunde con el enrollamiento del sentido" (Deleuze 1964, p. 110). Más adelante añade: "Todo es implicado, todo es complicado, todo es signo, sentido, esencia. Todo existe en estas zonas oscuras donde nosotros penetramos como si fueran criptas, para descifrar jeroglíficos y lenguajes secretos. [...] No existen cosas ni espíritus, no hay más que cuerpos: cuerpos astrales, cuerpos vegetales. . L La biología tendría razón si supiera que los cuerpos en sí mismos son ya lenguaje. Los lingüistas tendrían razón si supieran que el lenguaje es siempre el de los cuerpos" (Deleuze 1964, p. 112).

${ }^{11}$ Sobre la carne como visibilidad y su relación con la imagen, véase Carbone 2015. En este texto, Carbone retoma incluso la expresión de Merleau-Ponty "carne de lo imaginario" (p. 3).

${ }^{12}$ Gilbert Simondon, quien no por casualidad dedica su tesis doctoral a la memoria de Merleau-Ponty, desarrolla una ontología biológica de la membrana: "La membrana viviente, diferenciada anatómicamente o sólo funcional cuando ninguna formación particular materializa su límite, se caracteriza como lo que separa una región de interioridad de una región de exterioridad: la membrana se polariza, dejando pasar tal cuerpo en el sentido centrípeto o centrífugo, oponiéndose al pasaje de tal otro" (Simondon 2005, p. 225). La función de la membrana consiste en separar y, a la vez, conectar elementos del interior con elementos del exterior. Además, al mismo tiempo que permite el mantenimiento de una región de interioridad, es decir, la permanencia, siempre inestable, de una zona interna, la membrana se regenera por esa misma interioridad: "Se podría decir que lo viviente vive en el límite de sí mismo, sobre su límite: es por relación con este límite que hay una dirección hacia adentro y una dirección hacia afuera" (Simondon 2005, pp. 225-226). Por su parte, Deleuze retoma este concepto de Simondon para pensar los procesos de subjetivación en Foucault: "El pliegue mismo, el doblez, es una Memoria [...]. Memoria es el verdadero nombre de la relación sobre sí, o del afecto de sí por sí. [...] El tiempo como sujeto, como subjetivación, se llama memoria. En cuanto el afuera se pliega, un adentro le es coextensivo. El tiempo deviene sujeto porque, al plegar el afuera, produce un adentro como memoria" (Deleuze 2004, pp. 114115). Sin embargo, este adentro no designa una interioridad constituyente, sino una suerte de cavidad o enrollamiento del afuera. El adentro no es sino el afuera, el pliegue del afuera: "no es nunca una proyección del interior, sino, al contrario, una interiorización del afuera" (Deleuze 2004, p. 105). 
eso es preciso "mostrar —asegura Merleau-Ponty_ cómo el mundo se articula a partir de un cero de ser que no es una nada; es preciso instalarse sobre el borde del ser, ni en el para Sí ni en el en Sí, en la juntura, allí donde se cruzan las múltiples entradas del mundo" (Merleau-Ponty 1964a, p. 308). Por lo tanto, el quiasmo designa un cero de ser que no es una nada: un borde que posee un mínimo de ser. ${ }^{13}$ No sólo se trata de una ontología del borde sino, en cierta forma, de situarse en el borde mismo de la ontología. La carne del mundo no es ni un en sí ni un para sí, sino el borde o la juntura en el que ambos términos, como las dos imágenes en el quiasma óptico, se articulan y se cruzan. Todo Le visible et l'invisible está construido sobre este borde (del ser), sobre esta " $\mathrm{y}$ " (et) que separa, o más bien solapa, lo visible sobre lo invisible y lo invisible sobre lo visible. Le visible et l'invisible: grandeza de Merleau-Ponty con su ontología indirecta de la promiscuidad y del solapamiento. ${ }^{14}$

\section{IN-VISIBLE}

Se trata de una "diplopía ontológica" (cfr. Blondel 1935, p. 303), según la expresión de Maurice Blondel que retoma Merleau-Ponty. En efecto, en el résumé del curso dictado entre los años 1957 y 1958, MerleauPonty escribe: “¿No habría, como se ha dicho, una suerte de 'diplopía

\footnotetext{
${ }^{13}$ Acaso habría que decir del quiasmo, en la medida en que designa un cero de ser, lo que Alexius Meinong decía de los objetos no existentes: más que ex-sistir, in-sisten o sub-sisten: "los objetos ideales de hecho subsisten (bestehen), pero de ninguna manera existen (existieren) y, por lo tanto, no pueden ser actuales (wirklich). La semejanza y la diferencia son ejemplos de objetos de este tipo: quizá, en ciertas circunstancias, subsisten entre las realidades; pero no forman parte de la realidad en sí mismos" (Meinong 2011, p. 79). También sostiene, en relación con los objetos matemáticos, que "[l]a forma de ser (Sein) que concierne a las matemáticas no es nunca la existencia (Existenz). En este sentido, las matemáticas nunca trascienden la subsistencia (Bestand): una línea recta no tiene más existencia que un ángulo recto; un polígono regular no más que un círculo. Es una peculiaridad del uso matemático del lenguaje que este uso dé lugar a exigencias de existencia. Aunque el matemático utilice el término 'existencia', no puede sino aceptar que lo que podríamos llamar 'posibilidad' es, a fin de cuentas, todo lo que requiere el objeto de su consideración teórica" (Meinong 2011, pp. 80-81). Con base en las ideas de Meinong, Deleuze sostiene que el sentido, es decir, los acontecimientos, designan una suerte de extra-ser que, más que existir, insiste o subsiste: "Es este aliquid, a la vez extra-ser e insistencia, este mínimo de ser que conviene a las insistencias" (Deleuze 1969, p. 34).

${ }^{14}$ Sobre el problema de lo visible y lo invisible en relación con la mirada, véase Lapoujade 1999.
}

Diánoia, vol. LXIII, no. 80 (mayo de 2018). 
ontológica' (M. Blondel) de la que no se puede esperar ninguna reducción racional después de tantos esfuerzos filosóficos y a la que sólo se trataría de asumir enteramente, como la mirada asume imágenes monoculares para construir una única visión?" (Merleau-Ponty 1964a, p. 217). No se trata de resolver la diplopía en una identidad ni de considerar las dos imágenes monoculares, la del cuerpo y la del espíritu, la de lo visible y la de lo invisible, como dos sustancias radicalmente diferentes; se trata, parece sugerir Merleau-Ponty, de asumir la diplopía e instalarse en el quiasmo en el que ambas imágenes se integran y se solapan sin perder su especificidad. Este solapamiento de las dos imágenes, esta integración no sintética que se efectúa en el quiasmo, es de otro orden que las imágenes monoculares. "Las imágenes monoculares no son en el mismo sentido en que es la cosa percibida con los dos ojos" (Merleau-Ponty 1964a, p. 22). El solapamiento nos introduce en el mundo de la profundidad y de la verticalidad. La profundidad es, por cierto, inagotable. Siempre hay un resto de invisible en lo visible y un resto de visible en lo invisible. Por eso la integración de las imágenes monoculares no puede concebirse como una síntesis o una identidad, y cuando Merleau-Ponty sostiene que "más allá del ser en sí y el ser para nosotros, parece abrirse una tercera dimensión donde su discordancia se abole" (Merleau-Ponty 1964a, p. 48), no hay que entender que las diferencias entre las dos imágenes se anulan. La visión tridimensional, binocular, no cancela las diferencias específicas de cada imagen; más bien las hace coexistir, las deja ser (para decirlo con Heidegger) en su diferencia, pero integrándolas. ${ }^{15}$

${ }^{15}$ De nuevo es Simondon quien desarrolla esta idea y la eleva a una dimensión ontológica. El concepto de disparation (disparidad o discordancia) designa una tensión o una incompatibilidad entre dos elementos que forman parte de la misma situación y que sólo una nueva individuación puede resolver. Para Simondon, el caso paradigmático de disparation es, por cierto, la visión en profundidad, la cual se explica como la resolución de una disparidad entre las imágenes que perciben el ojo derecho y el ojo izquierdo. Estas dos imágenes bidimensionales dispares requieren una dimensión tridimensional que resuelva su tensión. "Así, cada retina está cubierta de una imagen bidimensional; la imagen izquierda y la imagen derecha son dispares; no pueden recubrirse porque representan el mundo de dos puntos de vista diferentes" (Simondon 2005, p. 208). Por lo tanto, esta disparidad fundamental crea las condiciones para que surja una tercera dimensión que la resuelva. Este nuevo sistema es justamente la visión tridimensional: "en el mundo tridimensional no hay más dos imágenes, sino el sistema integrado de las dos imágenes" (Simondon 2005 p. 208). La visión tridimensional integra de algún modo los detalles de cada una de las visiones bidimensionales sin suprimirlos. Lejos de retener lo que es común, la percepción retiene todo lo que es particular y lo integra al conjunto 
Ahora bien, hemos dicho que el concepto de quiasmo, tal como Merleau-Ponty lo entiende, puede (y debe) identificarse con la imaginación. La razón es que, a lo largo de la historia de la metafísica, la imaginación ha sido precisamente la instancia, muchas veces problemática y marginada, siempre difícil de aprehender, en la que lo sensible se articula o conecta con lo inteligible. Como sostiene James Engell en The Creative Imagination, "[1]a idea de la imaginación dramatizó y articuló la dialéctica entre materia y espíritu, naturaleza y psyché interior, materialismo y trascendentalismo" (Engell 1981, p. viii). ${ }^{16}$ En efecto, la imaginación ha funcionado como el pliegue o el quiasmo en el que el ojo del cuerpo y el ojo del alma, según una metáfora que se remonta a Platón, ${ }^{17}$ encuentran la posibilidad de su integración y coexisten-

del nuevo sistema tridimensional. Por este motivo, Alberto Toscano habla de una "dualidad original" o de "una suerte de diferencia originaria, an-árquica" en el pensamiento de Simondon (Toscano 2006, p. 139). Sin embargo, esta diferencia originaria, al igual que en Merleau-Ponty, no supone ningún dualismo ontológico, sino una tensión o incompatibilidad que sólo una nueva individuación puede resolver.

${ }^{16}$ Podríamos citar innumerables ejemplos que apoyan la existencia de este lugar intermedio, quiasmático, de la imaginación en relación con lo sensible y lo inteligible. Sin ir más lejos, Lodi Nauta y Detlev Pätzold sostienen, desde una perspectiva psicológica, que "[c]omo facultad del alma [la imaginación] se caracteriza en las teorías filosóficas, psicológicas y médicas por ser la mediadora entre los sentidos y la razón" (Nauta y Pätzold 2004, p. ix). Por su parte, John Cocking escribe que "en la tradición filosófica que surge de Aristóteles, la fantasía es el nexo entre la sensación y el espíritu, y en la teología de la emanación es el nexo en el proceso contrario; creando, el espíritu divino pasa de la pura inteligencia a la sustancia sensible a través de la imaginación" (Cocking 1991, p. 31). Desde esta misma perspectiva, John Lyons se refiere a la imaginación como "la forma de pensamiento que media entre el cuerpo y el intelecto" (Lyons 2005, p. xiii). Jan Veenstra expresa la misma idea: "Es una facultad intermedia entre los sentidos y la intelección, siguiendo a los primeros y precediendo a la última; una facultad entre lo corpóreo y lo incorpóreo" (Veenstra 2004, p. 14). Luigi Ambrosi también enfatiza la "extraña mezcolanza de su naturaleza a un tiempo material y espiritual" (Ambrosi 1898, p. xxx). Por último, Giorgio Agamben refiere que "[l]a imaginación recibe así un rango decisivo en todos los sentidos: en el vértice del alma individual, en el límite entre lo corpóreo y lo incorpóreo, lo individual y lo común, la sensación y el pensamiento, representa el residuo último que la combustión de la existencia individual abandona en el umbral de lo separado y de lo eterno. En este sentido, la imaginación - y no el intelectoes el principio definitorio de la especie humana" (Agamben 2007, pp. 51-52). El mismo autor añade un poco después: "es en la imaginación donde tiene lugar la fractura entre lo individual y lo impersonal, lo múltiple y lo único, lo sensible y lo inteligible y, a la vez, la tarea de su dialéctica recomposición" (Agamben 2007, p. 56).

${ }^{17}$ En el ensayo "Biblical Beauty. Hebrew, Greek, and Latin", David Konstan sostie- 
cia. Si, como afirma Agamben, en nuestra cultura "el hombre ha sido siempre pensado como la articulación y la conjunción de un cuerpo y de un alma, de un viviente y de un logos, de un elemento natural (o animal) y de un elemento sobrenatural, social o divino" (Agamben 2002, p. 21), y si identificamos el elemento natural, para seguir con la metáfora óptica, con la mirada que proviene del ojo del cuerpo y el elemento espiritual o anímico con la mirada que proviene del ojo del alma, entonces el quiasmo óptico es precisamente la imaginación. ${ }^{18}$ Instalarse en el borde del ser, como sugiere Merleau-Ponty cuando esboza su ontología, significa colocarse en la imaginación. ${ }^{19}$ Sin embargo, para

ne que "al parecer fue Platón quien acunó la expresión 'el ojo del alma'" (Konstan 2013, p. 134). Murray W. Bundy confirma la misma idea en el artículo "Plato's View of the Imagination": "Platón insiste entonces en que la verdad es un asunto de recta visión, y es el primero, por lo que sabemos, en hablar del ojo del alma. Sin embargo, en este punto de su pensamiento la imaginación no podría identificarse con ese

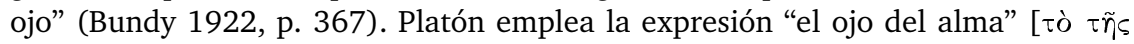

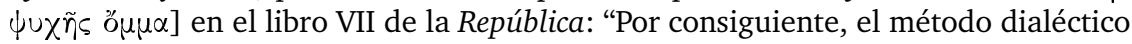
es el único que se dirige, cancelando los supuestos, hasta el principio mismo, a fin de consolidarse allí. Y dicho método empuja poco a poco al ojo del alma, cuando está sumergido realmente en el fango de la ignorancia, y lo eleva a las alturas, utilizando como asistentes y auxiliares para esta conversión a las artes que hemos

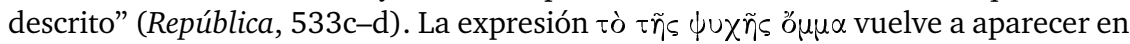
el Sofista, esta vez en plural ( $\tau \widetilde{\omega} \nu \psi u \times \tilde{n} \varsigma$ ö $\left.\mu_{\mu} \mu \alpha \tau\right)$ ), también en relación con el pensamiento dialéctico propio del filósofo. Por su parte, Heidegger en Platons Lehre von der Wahrheit, identifica la filosofía platónica con el inicio de la historia de la meta-

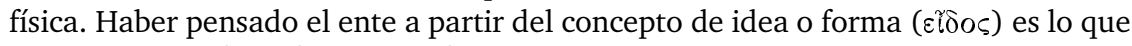
convertiría a la filosofía en metafísica. Según Heidegger, en Platón se produciría esa metamorfosis esencial del pensamiento occidental, esa conversión de la ontología en metafísica que sentaría las bases de la historia misma entendida como historia del olvido del ser. Leemos en el texto de Heidegger: "Desde Platón, el pensar sobre el ser del ente deviene 'filosofía', porque es un mirar ascendente hacia las 'ideas'. Pero esta 'filosofía' que comienza con Platón adquiere en lo sucesivo el carácter de lo que más tarde se llama 'metafísica', cuya forma fundamental ilustra el mismo Platón en la historia que narra la alegoría de la caverna" (Heidegger 1997, p. 235). Así, el inicio de la metafísica coincide con el ascenso de la mirada humana hacia las ideas, es decir, con la apertura del ojo del alma, el ojo que permite ver lo invisible.

${ }^{18}$ Este ojo imaginario, irreductible al ojo corpóreo y al ojo incorpóreo, posibilita una mirada también imaginaria. Se trata de un ojo cósmico u ontológico, y ya no sólo psicológico o subjetivo. En el artículo "Una mirada estética a lo invisible", cuyo eje es el pensamiento de Merleau-Ponty, Lapoujade habla precisamente de un ojo cósmico: "La mirada no es sin su fuente, el ojo. Entonces, la mirada que contiene el cosmos ha de provenir de un 'ojo cósmico'" (Lapoujade 1999, p. 64).

19 "La ontología nueva debe definir como Ser lo que no es plenamente y superar la dualidad entre ser y no-ser: ahora bien, lo imaginario es una noción que no puede pensarse sino más allá de este dualismo; ella permite entonces, al igual que la no- 
esto es necesario liberar la imaginación de toda connotación psicológica. En efecto, en una nota de febrero de 1959, Merleau-Ponty siente la necesidad de "mostrar que lo que se podría considerar 'psicología' (F. de la percepción) es en realidad ontología" (Merleau-Ponty 1964a, p. 228). Esto es aplicable sobre todo a la imaginación. ${ }^{20}$ Así como la imaginación, en Kant ${ }^{21}$ o en Bergson pero también en gran parte de la filosofía occidental, es la superficie de contacto de lo sensible y lo inteligible (de las intuiciones y los conceptos en Kant; de lo actual y lo virtual en Bergson), así también la imaginación es (o podría ser) el pliegue entre lo visible y lo invisible, entre el cuerpo y el espíritu en Merleau-Ponty. ${ }^{22}$ La imaginación es el lugar o, más bien, el no lugar, la superficie sin espesor en la que lo visible se solapa o se encabalga con lo invisible y viceversa; en la que el cuerpo encuentra su otro lado, su sombra espiritual, y el espíritu su sombra corporal, su lado sensible. Puede haber reversibilidad porque la imaginación es la bisagra que permite, desde ese lugar inextenso y casi inexistente, que el cuerpo y el espíritu se excedan mutuamente y se encabalguen: allí, en el no lugar de la imaginación, cuerpo y espíritu son Ineinander: uno en el otro. Así,

ción de carne, designar un modelo de ser que nosotros buscamos definir más allá de los dualismos" (Dufourcq 2012, p. 349). Por tal motivo, asegura Dufourcq, "lo imaginario se vuelve modelo ontológico" (Dufourcq 2012) en el último Merleau-Ponty.

${ }^{20}$ No puedo discutir aquí este asunto, pero es preciso indicar la importancia que posee el pensamiento de Schelling, y de los románticos en general, en la filosofía de Merleau-Ponty. Baste notar que la Naturphilosophie de Schelling significa para Merleau-Ponty, ante todo, una "fenomenología del Ser prerreflexivo" (Merleau-Ponty 1995, p. 66) que desemboca en una ontología de la naturaleza. Como se sabe, el romanticismo se caracteriza por una exaltación de la imaginación que, en el caso de Schelling pero también de Coleridge, Blake o Frohshammer, alcanza dimensiones ontológicas y metafísicas. Por ejemplo, en Die Philosophie der Kunst Schelling sostiene lo siguiente: "La espléndida palabra alemana 'imaginación' [Einbildungskraft] significa el poder de una mutua invención hacia la unidad [Ineinsbildung] sobre la cual se basa toda creación. Es la potencia por la que algo ideal es simultáneamente algo real, el alma simultáneamente el cuerpo, la potencia de la individuación que es el poder creativo real" (Schelling 1859, p. 386). Sobre la imaginación en el romanticismo, véanse Engell 1981 y Barth 1977. Sobre la influencia de Schelling en Merleau-Ponty, véanse Wirth y Burke 2013; Hamrick y Van der Veken 2011, pp. 123-144.

${ }^{21}$ Sobre el término kantiano Einbildungkraft, véanse en especial Lapoujade 1988, p. 74; Lapoujade 2013-2014, pp. 63-64.

${ }^{22}$ En una nota inédita que cita Emmanuel de Saint Aubert, Merleau-Ponty sostiene que lo imaginario no es una ilusión, sino un rasgo ontológico: "lo imaginario como hueco 'sensible', no es 'ilusión', sino rasgo ontológico del ser-visto" (nota inédita B.N. vol. VI [261]v, abril-mayo 1960, cit. en Saint Aubert 2004, p. 258, nota 5). 
la imaginación designa este entrelazo entre lo visible y lo invisible, el pliegue que debe pensar toda ontología que intente superar el dualismo sin renunciar a lo corporal y a lo espiritual, esto es, sin caer en una posición materialista ni idealista. En este sentido, Merleau-Ponty sostiene que la noción de carne, es decir, de quiasmo, posee un estatus autónomo que debe indagarse en su especificidad. Se trata, pues, de una noción última: "podemos mostrar que la carne es una noción última, que no es unión o compuesto de dos sustancias, sino pensable por sí misma" (Merleau-Ponty 1964a, p. 183). Es imperioso pensar esta suerte de tercer género del ser, en el sentido de la $\chi \omega \dot{\omega} \rho \alpha$ platónica, ${ }^{23} \mathrm{y}$ pensarlo en toda su profundidad y complejidad. Este tercer lugar o "tercera dimensión", como la llama Merleau-Ponty, este "cero de Ser que no es una nada", designa un tertium cuya función, paradójica y ambigua

23 "En nuestro discurso precedente nos bastaron dos géneros de Ser: siendo uno de ellos la Forma modelo, inteligible y existente de manera uniforme; y siendo el otro la copia del modelo, visible y sujeto al devenir. En aquel momento, no diferen-

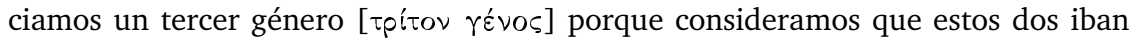
a ser suficientes. Pero ahora el argumento nos obliga a revelar con palabras una forma que es difícil y oscura. ¿En qué consiste? ¿Cuál es su naturaleza? Consiste en ser el receptáculo, y de algún modo la nodriza, de todo devenir" (Timeo, 48e-49a).

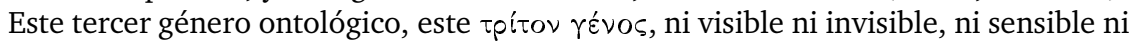
inteligible, designa más bien un lugar, un espacio: $\chi \omega ́ p \alpha$. Platón lo identifica, aunque sin dejar de señalar la imposibilidad de construir una identidad sobre lo que esta palabra nombra, con la madre, mientras que identifica las formas arquetípicas con el padre y a las copias con el hijo (véase Timeo, 50d). Este espacio, maternal y difícil de aprehender en la medida en que es capaz de recibir todas las formas, es en sí mismo amorfo (Timeo, 50d). En una línea similar, aunque sin hacer referencia al término $\chi \omega ́ p \alpha$, Anne Merker, en La Vision chez Platon et Aristote, ha sostenido la tesis de que, en Platón, lo visible sería en última instancia "un término medio, un lazo en el sentido particular de medialidad, entre lo sensible y lo inteligible"

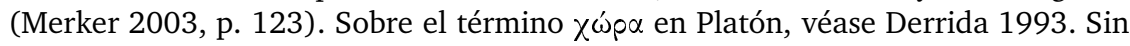
embargo, este tercer género de ser no se definiría por la existencia, sino, como indiqué a partir de Meinong, por la sub-sistencia o la in-sistencia. "No hay, en términos estrictos, lo sensible y lo inteligible, sino una única presencia que subsiste como la co-presencia de cada cosa en cada cosa, como pregnancia y promiscuidad universales" (Barbaras 2004, p. 304; las cursivas son mías). En la medida en que no es algo que ex-xiste, "el principio de su articulación [de lo sensible y lo inteligible] no puede ser otra cosa diversa de lo que articula" (Barbaras 2004, p. 306). Por tal motivo, Carbone, relacionando la noción de carne en Merleau-Ponty con la $\chi \omega ́ p \alpha$ platónica, aclara que no se trata de un “'tercer género', sino más bien de una textura unitaria de diferencias en constante diferenciación" (Carbone 2015, p. 72). En suma, lo sensible y lo inteligible existen; el quiasmo, insiste o subsiste. No sería, a decir verdad, un tercer género de ser, sino un extra ser insistente o subsistente. 
en extremo, consiste en conectar y, al mismo tiempo, distinguir dos elementos o regiones. Se trata de una suerte de conjunción disyuntiva. ${ }^{24}$ Además, esta operación es propia de lo que John Sallis denomina la "lógica de la imaginación":

La imaginación se sostiene entre términos diferentes, distintos y con frecuencia incluso opuestos. En este sostenerse entre términos, la imaginación los mantiene juntos. Esta conjunción no reduce la diferencia entre los términos. No los mezcla, no elimina sus rasgos distintivos; en el caso de los opuestos, no cancela su oposición. No produce lo que podríamos llamar una síntesis. Por el contrario, al mantener los términos juntos, la imaginación también sostiene su diferencia; al articular los opuestos, los mantiene en su oposición. (Sallis 2012, pp. 160-161) ${ }^{25}$

${ }^{24}$ Existe un término en química que creo que explica la función específica del quiasmo: "miscibilidad". La miscibilidad describe una mezcla de dos sustancias en la cual no hay transformación física o química de ninguna de ellas; cada una conserva tanto su composición química como sus propiedades físicas. Aunque no hay ningún cambio, las sustancias forman una mezcla homogénea, lo que significa que son visualmente indistinguibles. Por lo tanto, la miscibilidad designa una coexistencia de dos sustancias diferentes que, a pesar de integrarse y formar una mezcla homogénea, conservan sus rasgos específicos. Por ejemplo, el quiasmo óptico produce una suerte de miscibilidad de las dos imágenes monoculares, las cuales, como he dicho, no se sintetizan, sino que se integran en su disparidad para formar una imagen profunda o tridimensional. En cambio, la solubilidad es un término químico que se refiere a la capacidad de una sustancia, el soluto, para disolverse por completo en otra sustancia, el solvente. A diferencia de la miscibilidad, la solubilidad se refiere a un cambio físico en el que las moléculas se disuelven y se separan en la solución. En este caso, se trata de una síntesis que anula las diferencias respectivas; por el contrario, en el caso de la miscibilidad hay una integración que las conserva.

${ }^{25}$ Por razones de extensión no puedo desarrollar aquí esta idea. Sin embargo, nótese que existe una afinidad profunda entre la lógica de la imaginación, tal como Sallis la entiende, y lo que podríamos llamar una lógica del quiasmo o de la carne en Merleau-Ponty (véase, en particular, Sallis 2012, pp. 142-189). Además, es preciso indicar que ya en 1988 Lapoujade, en su excelente texto Filosofía de la imaginación, explicaba esta lógica, a la vez sintética y disyuntiva, en relación con el esquematismo kantiano: "Nótese que no se trata de una síntesis que amalgame los opuestos previos, que acabe con la dicotomía o la diversidad, sino que es una síntesis en que la diversidad se conserva, no queda abolida, porque en el elemento mediador subsisten, coexisten, las dos funciones: la sensible y la intelectual sin fusionarse" (Lapoujade 1988, p. 83; las cursivas son de la autora). Se trata, sostiene, "de una lógica al margen de la lógica racional, una lógica inherente a la imaginación" (Lapoujade 1988, p. 182). Además, en la medida en que es específica de la imaginación, sería una "lógica de la contradicción" (Lapoujade 1988, p. 99). Por otro lado, en el artículo "Un día en el transcurso de una memoria imaginante", Lapoujade establece una proximidad entre la lógica de la imaginación y la lógica

Diánoia, vol. LXIII, no. 80 (mayo de 2018). 


\section{Imaginación y subjetividad}

En Merleau-Ponty, el término "quiasmo" cumple una función operativa y sirve para pensar diferentes polaridades conceptuales. Su sentido general, como hemos visto, se caracteriza por la distinción entre lo "visible" y lo "invisible" o entre la "expresión" y la "percepción". Éste es el quiasmo de los quiasmos o, como sostiene Barbaras, el "último quiasmo" (véase Barbaras 2004, p. 306). ${ }^{26}$ No obstante, más allá de este quiasmo último, Merleau-Ponty también utiliza el concepto para pensar lo tocante y lo tocado, lo vidente y lo visible, lo visible y lo táctil, yo y mi cuerpo, mi cuerpo y el cuerpo del otro, etc. Ahora bien, entre los diferentes quiasmos individuados en Le visible et l'invisible, hay uno que me interesa en particular en relación con el sujeto: el de la pasividad y la actividad.

El quiasmo, la reversibilidad, es la idea de que toda percepción [...] es acto de dos caras, ya no se sabe quién habla ni quién escucha. Circularidad hablar-escuchar, ver-ser visto, percibir-ser percibido (es ella la que hace que nos parezca que la percepción se produce en las cosas) - Actividad $=$ pasividad. (Merleau-Ponty 1964a, p. 312; las cursivas son del autor)

Como resulta obvio, Merleau-Ponty piensa el quiasmo, en este caso vinculado con el círculo perceptivo, como el pliegue o la reversibilidad entre la actividad y la pasividad. ${ }^{27}$ Pero, ¿qué significa en concreto que lo activo equivalga a lo pasivo? O ¿qué significa afirmar, como en una nota de noviembre de 1960, que la "actividad no es más lo contrario de la pasividad"? (Merleau-Ponty 1964a, p. 317). La equivalencia entre la

del sueño o, mejor aún, de la ensoñación: "La lógica de la vigilia, la de la identidad y la no contradicción, cede su paso a la lógica de la ensoñación, que es la de carecer de lógica preestablecida" (Lapoujade 2002b, p. 163).

${ }^{26}$ En una nota de noviembre de 1960, Merleau-Ponty se pregunta "en qué sentido estos quiasmos múltiples no hacen más que uno" (Merleau-Ponty 1964a, p. 309). El último capítulo del libro de Barbaras, De l'être du phénomène. Sur l'ontologie de Merleau-Ponty, se titula precisamente "El último quiasmo". Para explicar el carácter inmanente de este concepto último de la ontología merleau-pontiana, Barbaras recurre a la noción de envoltura: "Tal es el sentido del último quiasmo: el mundo sensible y el mundo inteligible envuelven al Ser, pero el Ser no es otra cosa que ellos; por eso, para que el Ser pueda preservar su absoluta profundidad, lo sensible y lo inteligible son a su vez envueltos por el Ser" (Barbaras 2004, p. 306).

${ }^{27}$ Explica Carbone: "la idea de quiasmo [... . parece describir perfectamente la relación que hemos observado entre la actividad y la pasividad" (Carbone 2004, p. xvi). 
actividad y la pasividad, ¿implica una identidad? La respuesta, desde luego, es no. ${ }^{28}$ Dejemos que Merleau-Ponty responda:

Es que reversibilidad no es identidad actual de lo tocante y de lo tocado. Es su identidad de principio (siempre faltante). No es, sin embargo, idealidad, pues el cuerpo no es simplemente un visible entre los visibles, es visiblevidente, o mirada. Dicho de otro modo, el tejido de posibilidades que encierra lo visible exterior sobre el cuerpo vidente mantiene entre ellos una cierta distancia [écart]. Pero esta distancia no es un vacío, se llena justo por la carne como lugar de emergencia de una visión pasividad que implica una actividad - y, por lo mismo, distancia entre lo visible exterior y el cuerpo que constituye una amortiguación contra el mundo-. (MerleauPonty 1964a, p. 320)

Se trata de la misma lógica que explicaba la relación entre lo visible y lo invisible. Hay un solapamiento entre la pasividad y la actividad, hay pregnancia: lo activo se impregna de lo pasivo y lo pasivo de lo activo. ¿Qué es el sujeto? Es esta distancia que no es un vacío, de la misma manera en que el quiasmo designa un cero de ser que no es una nada. Esto significa que el sujeto coincide con el quiasmo, es decir, con la imaginación. ${ }^{29}$ El sujeto es cierto espesor, una distancia, el punto de reversibilidad en el que lo pasivo y lo activo se vuelven prácticamente indistinguibles. No es una cosa, no es un espíritu, no es una sustancia: es carne. Por esa razón, Merleau-Ponty sostiene que "la idea del quiasmo [supone que] toda relación con el ser es simultáneamente aprehender y ser aprehendido, la aprehensión es aprehendida, está inscrita y se inscribe en el mismo ser que ella aprehende" (Merleau-Ponty 1964a, p. 313). El sujeto, en rigor de verdad, no es ni activo ni pasivo o, quizá, es las dos cosas al mismo tiempo: es quien aprehende y quien es aprehendido, quien aprehende en la medida en que es aprehendido, quien ve y es visto, quien ve en cuanto que es visto. En L'œil et l'esprit, Merleau-Ponty habla de una suerte de respiración ontológica que explica este doble movimiento del sujeto: "Lo que se llama inspiración

\footnotetext{
28 "No hay coincidencia entre lo vidente y lo visible" (Merleau-Ponty 1964a, p. 309).

${ }^{29}$ Según Dufourcq, "[e]1 Ser tal como lo concibe Merleau-Ponty va a llevar la huella del arquetipo imaginario. Nosotros vamos a mostrar que es fundamentalmente distancia [écart], dehiscencia, ubiquidad, no coincidencia consigo mismo, Urstiftung mítica —inasignable- - Es la fluidez y el deslizamiento mismos. Es justo el carácter evasivo y evanescente de lo imaginario lo que hace que adopte el rango de modelo ontológico" (Dufourcq 2012, p. 350).
} 
debería tomarse al pie de la letra: hay en verdad inspiración y expiración del Ser, respiración en el Ser, acción y pasión tan poco discernibles que no se sabe ya quién ve y quién es visto, quién pinta y quién es pintado" (Merleau-Ponty 1964b, pp. 31-32). El sujeto, como el ser, el sujeto como parte del ser, no está separado de esa respiración, no es una conciencia constituyente, sino que es primero carne, pliegue o envoltura ontológica. El sujeto es el punto en el que la in-spiración se transforma en ex-piración, el instante en el que la pasividad se vuelve activa, y al mismo tiempo en el que la actividad se vuelve pasiva. La respiración requiere ambos movimientos. Ahora bien, este doble movimiento, lejos de conferirle al sujeto un papel constituyente y fundamental, le adjudica más bien una función de actualización. El sujeto se define como una ocasión de actualización: actualiza una potencia anónima e impersonal. "Es esta Visibilidad, esta generalidad de lo Sensible en sí, este anonimato innato de Mí-mismo que nosotros llamamos carne hace un momento" (Merleau-Ponty 1964a, p. 181). Podemos ver porque actualizamos esta "Visibilidad" en general, de la misma manera que podemos sentir porque actualizamos este "Sensible en sí". Esta potencia, en el sentido de posibilidad anónima de actualización, es la carne. De allí el énfasis que pone Merleau-Ponty en el aspecto impersonal de la visibilidad. ¿Cuándo se produce la visión? ¿Cuándo vemos? Cuando lo visible, la visibilidad en general, se pliega sobre sí, se solapa sobre sí y, al hacerlo, nos constituye como videntes: "hay una relación consigo mismo de lo visible que me atraviesa y me constituye como vidente, este círculo que yo no hago, que me hace, este enrollamiento de lo visible sobre lo visible" (MerleauPonty 1964a, p. 183; las cursivas son mías). He aquí el aspecto pasivo: yo no hago la visión, la visión me hace, me atraviesa. ¿Qué soy? Este rulo, esta suerte de espiral o torbellino que forma lo visible cuando entra en relación consigo mismo. En esta especie de cavidad o repulgo del ser, puede aparecer algo así como un sujeto. Llamamos sensibilidad al pliegue de lo sensible e inteligibilidad al pliegue de lo invisible. Ambos pliegues se solapan además entre sí. Así como sentir es actualizar un sensible en sí, pensar es actualizar un inteligible en sí. El mundo se siente y se piensa a través nuestro: "se puede decir que nosotros percibimos las cosas mismas, que somos el mundo que se piensa -o que el mundo es en el corazón de nuestra carne--" (Merleau-Ponty 1964a, p. 177). El sujeto es una ocasión de expresión del ser, del mundo. ${ }^{30}$

\footnotetext{
${ }^{30}$ Como refiere Barbaras: "Hay que observar que Merleau-Ponty no se preocupa demasiado en clarificar el uso de estos términos [mundo y Ser], los cuales tiende a confundir" (Barbaras 2004, p. 308); y un poco más adelante: "De hecho, mundo y Ser no pueden oponerse o distinguirse; hacerlo implicaría desfigurar a ambos.
} 
Merleau-Ponty recurre a Marcel Proust para ilustrar esta concepción quiasmática del sujeto. El caso ejemplar es el del músico. El intérprete no ejecuta la sonata; es más bien al contrario: el músico es la ocasión que encuentra la sonata para expresarse, para actualizarse.

A las ideas musicales o sensibles, justo porque son negatividad o ausencia circunscrita, no las poseemos, ellas nos poseen. No es el ejecutante el que produce o reproduce la sonata: él se siente, y los otros lo sienten, al servicio de la sonata, es ella la que canta a través de él o la que grita tan bruscamente que él debe "precipitarse sobre su arco" para seguirla. Y estos torbellinos abiertos en el mundo sonoro no hacen finalmente más que uno donde las ideas se ajustan una a la otra. (Merleau-Ponty 1964a, p. 196) ${ }^{31}$

Los sujetos no son sino estos torbellinos abiertos en el mundo sonoro, pero también en el mundo sensible, en el mundo afectivo, en el mundo inteligible. Torbellinos abiertos porque nunca puede agotarse la profundidad del ser, porque nunca puede clausurarse la totalidad de lo que es. Siempre hay un misterio que excede lo que se abarca con la mirada, con el pensamiento, con la sensibilidad. Toda percepción es impercepción, todo pensamiento implica un impensado. El sujeto no es identidad, pero tampoco no identidad; no es coincidencia, pero tampoco no coincidencia; es el quiasmo entre el adentro y el afuera, el pliegue en el que el afuera se adentra en sí mismo y, al hacerlo, provoca el advenimiento de una cavidad subjetiva. Adentro y afuera describen un movimiento circular que podríamos denominar círculo de la subjetividad: "Partir de esto: no hay identidad, ni no identidad, o no coincidencia, hay adentro y afuera girando uno alrededor del otro: $\mathrm{mi}$

El Ser hace sentido, se conserva en su absoluta Diferencia, sólo si no posee su propia positividad que le permitiría separarse del mundo, es decir, retirarse del plano del mundo. Su misma profundidad requiere que no se distinga de la experiencia, del mundo entendido en la plenitud de su sentido, o sea, como mundo sensible y mundo inteligible" (Barbaras 2004, p. 309).

${ }^{31}$ Merleau-Ponty expresa la misma idea en las notas de los cursos dictados en el Collège de France sobre la naturaleza: "Cuando inventamos una melodía, más que ser cantada por nosotros, ella se canta en nosotros [. . . ] el cuerpo queda suspendido en lo que canta, la melodía se encarna y encuentra en él una especie de sirviente" (Merleau-Ponty 1995, p. 228). En un comentario a este pasaje, Carbone sostiene que en Merleau-Ponty la subjetividad se piensa como un vacío o un hueco en el que la pasividad y la actividad se vuelven inescindibles: "En suma, en su forma de vacío, la subjetividad revela su propia pasividad como creadora de las ideas. De hecho, si la idea debe entenderse como algo que llega a la subjetividad, entonces esto significa que se crea pasivamente alli" (Carbone 2004, p. xv). Esta pasividad creadora o creatividad pasiva es, en mi opinión, lo propio de la imaginación.

Diánoia, vol. LXIII, no. 80 (mayo de 2018). 
nada 'central' es como la punta de la espiral estroboscópica, que está no se sabe dónde, que es 'nadie"' (Merleau-Ponty 1964a, p. 312).

Es interesante notar que también la imaginación desempeña este papel de bisagra entre lo activo y lo pasivo. ${ }^{32}$ De nuevo son los románticos quienes lo expresan con gran claridad. Cito un pasaje de la Biographia literaria de Samuel Taylor Coleridge:

Existen con toda evidencia dos poderes en funcionamiento, uno de los cuales es pasivo y el otro activo; y esto no es posible sin una facultad intermediaria, la cual es al mismo tiempo activa y pasiva. (En términos filosóficos, debemos denominar a esta facultad intermediaria en todos sus grados y determinaciones, IMAGINACIÓN.) (Coleridge 1907, p. 86) ${ }^{33}$

Esta idea, central también en Shelley y Schelling, remite, aunque en una perspectiva psicológica, a un autor caro a los románticos: Immanuel Kant. En efecto, para el filósofo de Königsberg la imaginación permite articular el aspecto reproductivo o pasivo con el aspecto productivo o activo. Por eso posee una función doble: imaginación reproductiva e imaginación productiva. ${ }^{34}$ En la Kritik der reinen Vernunft, la imaginación es una suerte de superficie de doble faz: por un lado, tiene una

${ }^{32}$ Lapoujade ha mostrado que en Kant la unidad originaria de la apercepción presupone a fin de cuentas la síntesis de la imaginación; es decir, que el yo trascendental es un efecto de la imaginación: "la unidad originaria presupone la síntesis. La síntesis es antes que la unidad que de ella deriva" (Lapoujade 1988, p. 79); y concluye, un poco después: "la síntesis trascendental de la imaginación es en última instancia la que hace posible la experiencia" (Lapoujade 1988, p. 79; las cursivas son de la autora).

${ }^{33}$ Sobre Coleridge y la imaginación, véanse Leadbetter 2011; McNiece 1992, pp. 53-61; Lapoujade 1988, pp. 137-138.

${ }^{34}$ Sin ir más lejos, Coleridge distingue dos tipos de imaginación: una primaria y una secundaria. Para este autor, como para la mayoría de los románticos, la imaginación es la potencia que unifica al hombre con el resto de la naturaleza. Cuando imagina, el hombre crea como crea la naturaleza; es más, al ejercer su potencia imaginativa, el hombre asume su condición natural, vive como vive el cosmos, como vive Dios. Coleridge sostiene que la imaginación primaria es la repetición en el hombre de la actividad creadora de lo infinito: "Entonces, considero a la IMAGINACIÓN o bien primaria o bien secundaria. La imaginación primaria es el Poder viviente y el primer Agente de toda la Percepción humana, y Yo soy como una repetición en la mente finita del acto eterno de creación en el infinito. La imaginación secundaria es un eco de la primaria y coexiste con la voluntad consciente, aunque es idéntica no obstante a la primaria en el fondo de su agencia, y difiere sólo en grado y en el modo de su operación" (Coleridge 1907, p. 202). La imaginación primaria es una fuerza metafísica, similar a la concepción de la naturaleza — también organicista- que encontramos en Schelling. Por su parte, la imaginación secundaria sólo difiere en 
cara que se orienta hacia a la sensibilidad, es decir, hacia la pasividad o receptividad; por otro lado, su otra cara se orienta hacia el entendimiento, es decir, hacia la actividad o espontaneidad. ${ }^{35}$ Podríamos resumir todo esto diciendo, con Wolfgang Iser, que la imaginación posee una dimensión estética y una dimensión artística o poética. ${ }^{36}$

grado de la primaria y representa la misma potencia pero unida ahora a la voluntad consciente. Para un panorama general de las diversas interpretaciones de estas dos modalidades de la imaginación en Coleridge, véase McNiece 1992, pp. 58-59.

${ }^{35}$ Por supuesto, en este lugar intermedio entre los conceptos y las intuiciones se ubican los esquemas de la imaginación. No es casual que John Sallis señale la necesidad de pensar una lógica que no se base ni en las categorías inteligibles ni en las meras experiencias sensibles, sino en los esquemas de la imaginación. "La lógica de los conceptos debe dar lugar a una lógica que se enfoque en la forma que adopta la determinación primaria cuando ya no es prescrita desde el exterior (por ejemplo, mediante las categorías), sino reinstalada en lo sensible. Esta operación de determinación primaria en lo sensible debe designarse a partir de una adaptación del término esquema. Y, dado que esta operación de los esquemas pertenece a la imaginación, la lógica centrada en tal determinación tomará la forma de una lógica de la imaginación" (Sallis 2012, p. 22). Esta lógica de la imaginación, cuya operación se define por una conjunción disyuntiva, se ubica en el quiasmo entre lo visible y lo invisible, entre lo sensible y lo inteligible: en el esquema. Se trata de una lógica de lo que se expresa en la percepción y de lo que se percibe en la expresión o, dicho de otro modo, de la pregnancia invisible de lo visible y de la pregnancia visible de lo invisible: una lógica de la carne.

${ }^{36}$ En el capítulo sexto de The Act of Reading. A Theory of Aesthetic Response, Iser sostiene que el proceso de lectura, a través del cual se concretiza el sentido de una obra literaria, se caracteriza por una polaridad esencial: de un lado, el texto escrito por el autor (polo artístico); del otro, el lector que actualiza el texto (polo estético). Iser señala la importancia que posee la imaginación, entendida como la facultad capaz de crear imágenes mentales, a la hora de comprender la lectura de un texto literario. No sólo la comprensión y el sentido del texto dependen de esta facultad, sino que ella indica el lugar (o no lugar) en el que el mundo del texto y el mundo del lector se articulan. "Resulta extremadamente difícil decir dónde terminan las señales y dónde comienza la imaginación del lector en este proceso de proyección" (Iser 1980, p. 135). Un poco más adelante, añade: "Lo que el lenguaje dice es trascendido por lo que encubre, y lo que encubre representa su verdadero significado. El sentido de la obra literaria permanece vinculado con lo que dice el texto impreso, pero requiere la imaginación creativa del lector para concretizarlo" (Iser 1980, p. 142). Además, según él mismo, el lugar propio de la obra de arte literaria se encuentra entre el texto y el lector. Iser denomina a ese espacio intermedio "posición virtual" [virtual position] (Iser 1980, p. 21).

Diánoia, vol. LXIII, no. 80 (mayo de 2018). 


\section{Conclusión}

En las páginas previas sostuve que el concepto de "quiasmo" es un terminus technicus clave en la ontología esbozada por Merleau-Ponty en sus últimos años. Esta categoría permite pensar una ontología binocular o de doble faz ${ }^{37}$ (visible e invisible, cuerpo y espíritu, naturaleza y lenguaje, etc.) sin caer en un dualismo o en un reduccionismo. Como sostiene con lucidez Barbaras: "La percepción y la expresión no pueden confundirse, pero tampoco pueden oponerse, y por las mismas razones" (Barbaras 2004, p. 303). Lo visible envuelve ya un margen de invisibilidad, así como lo invisible envuelve un margen de visibilidad. Esta doble articulación o solapamiento, esta reversibilidad, es justo el quiasmo o la carne. He querido mostrar, además, que esta función estratégica del término "quiasmo" en Merleau-Ponty es similar a la función que desempeña la imaginación a lo largo de la historia de la metafísica. En efecto, la imaginación ha sido el quiasmo, es decir, el pliegue o la bisagra que ha permitido articular las grandes polaridades del Occidente: lo sensible y lo inteligible, el cuerpo y el alma, la materia y el espíritu, etc. Desde Aristóteles a Bergson, pasando por Averroes y Kant, la imaginación (a veces llamada "fantasía") funciona como el punto de contacto de las dos grandes regiones ontológicas que Platón legó a la posteridad: las ideas inteligibles y las cosas sensibles. Sin embargo, a pesar de esta función decisiva, o tal vez a causa de ella, la imaginación ha permanecido en una suerte de exterioridad respecto de las grandes dicotomías metafísicas. Acaso no sería osado afirmar que la potencia imaginativa es el gran impensado del mundo occidental. Esto es así porque, en cierto sentido, la imaginación, es decir, el quiasmo, designa un límite que, en rigor de verdad, no ex-iste, sino que más bien in-siste o sub-siste. Se trata de un extra-ser o, como sostiene Merleau-Ponty, un cero de ser que no es una nada: una ontología del partage. ${ }^{38}$ Por eso, la metafísica

${ }^{37}$ La expresión "doble faz" pretende traducir el término inglés "twofold". Es preciso no confundir, puesto que se oponen, la doble cara de la ontología merleaupontiana con el dualismo en cualquiera de sus modalidades. El segundo capítulo de Nature and Logos, el notable texto de William Hamrick y Jan Van der Veken al que ya hice referencia, se dedica por completo a indagar sobre la influencia de Alfred North Whitehead en la "ontología de doble faz" [twofold ontology] del último Merleau-Ponty (véase Hamrick y Van der Veken 2011, pp. 47-72).

${ }^{38}$ Dale Jacquette, en su explicación de la teoría de los objetos no existentes de Meinong, sugiere la expresión (por cierto problemática pero interesante) extraontología: "El intensionalismo de Meinong sobrepasa por completo al extensionalismo, y añade a la ontología una extraontología [extraontology] de objetos no existentes que satisfacen el criterio leibniziano de autoidentidad" (Jacquette 2015, p. 17). 
occidental, enfocada en pensar el ser, no ha sido capaz de aprehender esta exterioridad paradójica y ambigua que define a la imaginación.

De la misma manera, la imaginación funciona como el quiasmo entre la pasividad y la actividad. El sujeto, como dije, no es ni meramente pasivo ni meramente activo, es más bien la distancia [écart] que se abre entre ambos movimientos, distancia que no es sino su punto de contac-

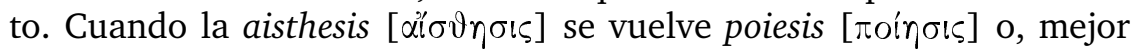
aún, cuando resulta imposible distinguir una de otra podemos decir que hay un sujeto. Por ello, el sujeto es el quiasmo entre la dimensión estética, pasiva, y la dimensión poética, activa. En cierto sentido, al igual que el quiasmo ontológico, el sujeto es también un ser en el límite del ser que no coincide - para decirlo en términos kantianos- ni con la receptividad de la sensibilidad ni con la espontaneidad del entendimiento. El sujeto es su punto de contacto, su límite de reversibilidad: la imaginación. ${ }^{39}$ Acaso no existimos, al menos como existe la materia o el espíritu o como existen las cosas y las representaciones; acaso estamos condenados (o librados) a un mínimo de ser, a un cero de ser que, como el de los fantasmas que se aparecen en nuestros sueños, no es una simple nada, sino una in-sistencia o una sub-sistencia en el borde mismo de la ontología. ${ }^{40}$ Sin duda, esta fragilidad ontológica es lo más difícil de pensar. Algunos se han arriesgado a llamarla imaginación, otros carne o quiasmo, aunque "se sabe que no hay nombre en la filosofía tradicional para designar esto" (Merleau-Ponty 1964a, p. 181).

\footnotetext{
${ }^{39}$ No es para nada casual que Lapoujade retome la expresión homo imaginans para definir al ser humano: "Homo imaginans, el hombre imaginante; el hombre entendido como el ser que imagina" (Lapoujade 1988, p. 198). Por otro lado, en el artículo "La imaginación y sus imaginarios como paideia", Lapoujade sostiene que la capacidad de imaginar es "la característica que particulariza a la especie humana y, sin la cual, ésta sería inconcebible” (Lapoujade 2013-2014, p. 60). A ello habría que agregar también la expresión homo imaginatus, puesto que no sólo imagina, sino que es imaginado por la potencia impersonal de la imaginación.

${ }^{40}$ En un notable ensayo sobre la imaginación en Gaston Bachelard y MerleauPonty, Annabelle Dufourcq expresa una idea similar con las siguientes palabras: "De hecho, nosotros, quienes imaginamos el cosmos, somos activos y, al mismo tiempo, soportados y constituidos por una cosmogénesis que nos precede. Esta cosmogénesis consiste en un sueño [dream] del cosmos que surge del mundo y que también se realiza a través de nosotros" (Dufourcq 2016, pp. 55-56); o también, de forma más lacónica: "el mundo sueña el cosmos a través de nosotros" (Dufourcq 2016, p. 56).
}

Diánoia, vol. LXIII, no. 80 (mayo de 2018). 


\section{BIBLIOGRAFÍA}

Agamben, G., 2002, L'aperto: l'uomo e l'animale, Bollati Boringhieri, Turín.

— 2007, Ninfe, Bollati Boringhieri, Turín.

Ambrosi, L., 1898, La psicologia della immaginazione nella storia della filosofia, Società Editrice Dante Alighieri, Roma.

Bachelard, G., 2005, Causeries (1952-54), Il Melangolo, Nápoles.

Barbaras, R., 2004, The Being of the Phenomenon. Merleau-Ponty's Ontology, trad. T. Toadvine y L. Lawlor, Indiana University Press, Bloomington/Indianápolis.

Barth, R.J., 1977, The Symbolic Imagination. Coleridge and the Romantic Tradition, Princeton University Press, Princeton, Nueva Jersey.

Bergson, H., 1939, Matière et mémoire. Essai sur la relation du corps à l'esprit, Presses Universitaires de France, París.

Blondel, M., 1935, L'être et les êtres, Félix Alcan, París.

Bundy, M.W., 1922, "Plato's View of the Imagination", Studies in Philology, vol. 19, no. 4, pp. 362-403.

Carbone, M., 2004, The Thinking of the Sensible. Merleau-Ponty's A-Philosophy, Northwestern University Press, Evanston, Illinois.

_ 2015, The Flesh of Images. Merleau-Ponty between Painting and Cinema, New York University Press, Nueva York.

Cocking, J., 1991, Imagination: A Study in the History of Ideas, Routledge, Londres.

Coleridge, S.T., 1907, Biographia Literaria, Clarendon Press, Oxford.

Deleuze, G., 1964, Proust et les signes, Presses Universitaires de France, París.

— 1966, Le bergsonisme, Presses Universitaires de France, París.

— 1969, Logique du sens, Les Éditions de Minuit, París.

— 2002, Francis Bacon: logique de la sensation, Éditions du Seuil, París.

— 2004, Foucault, Les Éditions de Minuit, París.

Deleuze, G. y F. Guattari, 2005, Qu'est-ce que la philosophie?, Les Éditions de Minuit, París.

Derrida, J., 1993, Khôra, Galilée, París.

Dufourcq, A., 2012, Merleau-Ponty: une ontologie de l'imaginaire, Springer, Nueva York.

_ 2016, "Bachelard and Merleau-Ponty. Is a Cosmic Flesh of the World Feigned or Disclosed by Imagination?", en A.-T. Tymieniecka y P. TruttyCoohill (comps.), The Cosmos and the Creative Imagination, Springer (Analecta Husserliana. The Yearbook of Phenomenological Research, CXIX), Nueva York, pp. 43-58.

Dupond, P., 2001, Le vocabulaire de Merleau-Ponty, Ellipses, París.

Engell, J., 1981, The Creative Imagination. Enlightenment to Romanticism, Harvard University Press, Cambridge/Londres.

Esposito, R., 2006, Bíos. Biopolítica y filosofía, trad. C.R. Molinari Maroto, Amorrortu, Buenos Aires. 
Evans, F. y L. Lawlor (comps.), 2000, Chiasms: Merleau-Ponty's Notion of Flesh, New York University Press, Nueva York.

Galeno, C., 1978, "De usu partium corporis humani”, en I. Garofalo y M. Vegetti (comps.), Opere scelte, Unione Tipografico/Editrice Torinese, Turín, pp. 292832.

Hamrick, W.S. y J. Van der Veken, 2011, Nature and Logos. A Whiteheadian Key to Merleau-Ponty's Fundamental Thought, New York University Press, Nueva York.

Heidegger, M., 1997, Platons Lehre von der Wahrheit, Vittorio Klostermann, Fráncfort del Meno.

Henry, M., 2000, Incarnation. Une philosophie de la chair, Éditions du Seuil, París.

Iser, W., 1980, The Act of Reading. A Theory of Aesthetic Response, Johns Hopkins University Press, Londres.

Jacquette, D., 2015, Alexius Meinong, the Shepherd of Non-Being, Springer, Nueva York.

Kant, I., 1956, Kritik der reinen Vernunft, Felix Meiner, Hamburgo.

Konstan, D., 2013, "Biblical Beauty. Hebrew, Greek, and Latin", en C. Johnson Hodge et al. (comps.), "The One Who Sows Bountifully": Essays in Honor of Stanley K. Stowers, Brown Judaic Studies, Rhode Island, pp. 129-140.

Lapoujade, M.N., 1988, Filosofía de la imaginación, Siglo XXI, México.

—_, 1999, "Una mirada estética a lo invisible", Revista de Filosofía, vol. 33, no. 3, pp. 61-77.

—_, 2002a, La imaginación estética en la mirada de Vermeer, Herder, México.

—_, 2002b, "Un día en el transcurso de una memoria imaginante", Signos Filosóficos, vol. 4, no. 7, pp. 151-173.

—, 2005, "Kant-Proust: une rencontre esthétique", en J. Ferrari et al. (comps.), Kant et la France - Kant und Frankreich, Georg Olms/Hildesheim, Zúrich/Nueva York, pp. 157-167.

—_ 2009, "Mito e imaginación a partir de la poética de Gaston Bachelard", en Solares 2009, pp. 33-58.

_, $2013-2014$, "La imaginación y sus imaginarios como paideia", Temas Antropológicos. Revista Científica de Investigaciones Regionales, vol. 36, no. 1, pp. 55-72.

Leadbetter, G., 2011, Coleridge and the Daemonic Imagination, Palgrave Macmillan, Nueva York.

Lyons, J., 2005, Before Imagination: Embodied Thought from Montaigne to Rousseau, Stanford University Press, Stanford, California.

Mazis, G.A., 2016, Merleau-Ponty and the Face of the World. Silence, Ethics, Imagination, and Poetic Ontology, State University of New York Press, Nueva York.

McNiece, G., 1992, The Knowledge that Endures: Coleridge, German Philosophy and the Logic of Romantic Thought, Palgrave Macmillan, Nueva York.

Diánoia, vol. LXIII, no. 80 (mayo de 2018). 
Meinong, A., 2011, "The Theory of Objects", en R.M. Chisholm (comp.), Realism and the Background of Phenomenology, trad. I. Levi, D.B. Terrell y R. Chisholm, Free Press, Glencoe, Illinois, pp. 76-117.

Merker, A., 2003, La Vision chez Platon et Aristote, Academia, Sankt Augustin. Merleau-Ponty, M., 1964a, Le visible et l'invisible, Gallimard, París.

— 1964b, L'œeil et l'esprit, Gallimard, París.

_ 1995, La nature. Notes et cours du Collège de France, Éditions du Seuil, París.

Nauta, L. y D. Pätzold (comps.), 2004, Imagination in the Later Middle Ages and Early Modern Times, Peeters, Lovaina.

Platón, 1986-1988, Diálogos, vol. IV, República, trad. C. Eggers Lan, Gredos, Madrid.

—_ 1992, Timeo, en Diálogos, vol. VI, Filebo. Timeo. Critias, trad. F. Lisi, Gredos, Madrid, pp. 125-261.

Saint Aubert, E., 2004, Du lien des êtres aux éléments de l'être. Merleau-Ponty au tournant des années 1945-1951, Vrin, París.

Sallis, J., 2012, Logic of Imagination. The Expanse of the Elemental, Indiana University Press, Bloomington/Indianápolis.

Schelling, F., 1859, "Philosophie der Kunst", en Sämtliche Werke, secc. 1, vol. 5., J.G. Cotta, Stuttgart, pp. 353-736.

Septuaginta: Vetus Testamentum Graecum, 1926-, ed. A. Rahlfs, Vandenhoeck \& Ruprecht, Gotinga.

Simondon, G., 2005, L'individuation à la lumière des notions de forme et d'information, Jérôme Millon, Grenoble.

Solares, B. (comp.), 2009, Gaston Bachelard y la vida de las imágenes, Centro Regional de Investigaciones Multidisciplinarias-UnAM, Cuernavaca.

Suidas, 1705, Suidae lexicon. Graece et latine, trad. latina A. Portus, ed. L. Küster, Typis Academicis, Cambridge.

Toadvine, T., 2009, Merleau-Ponty's Philosophy of Nature, Northwestern University Press, Evanston, Illinois.

_ 2012, "The Chiasm", en L. Sebastian y O. Søren (comps.), The Routledge Companion to Phenomenology, Routledge, Nueva York, pp. 336-347.

Toscano, A., 2006, The Theatre of Production. Philosophy and Individuation between Kant and Deleuze, Palgrave Macmillan, Nueva York.

Veenstra, J.R., 2004, “The Subtle Knot”, en L. Nauta y D. Pätzold 2004, pp. 120.

Wirth, J.M. y P. Burke (comps.), 2013, The Barbarian Principle: Merleau-Ponty, Schelling, and the Question of Nature, University of New York Press, Nueva York.

Recibido el 31 de octubre de 2016; revisado el 28 de junio de 2017; aceptado el 23 de octubre de 2017. 